\title{
Kontrast, ultralyd og levermetastaser
}

Video på www.tidsskriftet.no

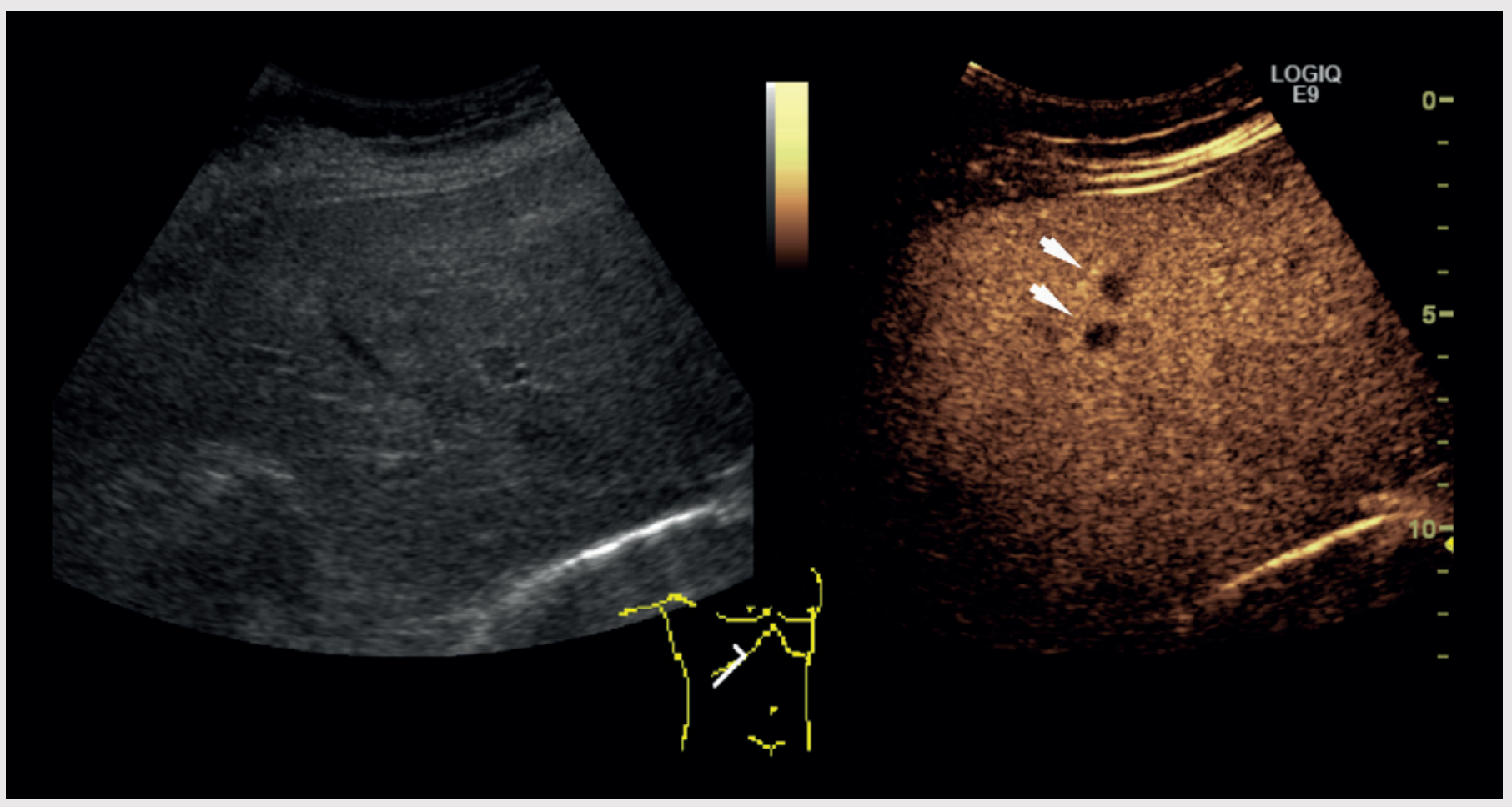

Kontrastforsterket ultralydundersøkelse av leveren er en metode for deteksjon og karakterisering av fokale lesjoner. Kontrastmidlet, som består av en oppløsning med gassfylte mikrobobler, injiseres intravenøst. Hver enkelt boble er mindre enn en erytrocytt. Boblene sirkulerer fritt i blodstrømmen inntil de etter noen minutter sprekker og gassen pustes ut.

På bildet over til venstre vises et konvensjonelt ultralydbilde gjennom leveren, til høyre det korresponderende kontrastforsterkede bildet. Det kontrastforsterkede bildet er tatt i sen kontrastfase, og man kan se flere typiske metastaser som mørke flekker på lys bakgrunn (se video på nett for fremstilling av hele høyre leverlapp). Eksemplet viser en metastase fra tykktarmskreft. Det er betydelig lettere å identifisere metastasene på de kontrastforsterkede bildene.

Kontrastforsterket ultralydundersøkelse inngår nå som ledd i bildediagnostisk oppfølging etter kurativ behandling for kreft $\mathrm{i}$ tykktarm og endetarm (1). Denne undersøkelsen har tilnærmet lik sensitivitet som CT-undersø- kelse for deteksjon av metastaser - og signifikant høyere sensitivitet enn konvensjonell ultralydundersøkelse (2). Metoden innebærer ingen ioniserende stråling eller bruk av potensielt nefrotoksiske kontrastmidler. Unders $ø$ kelsen er brukeravhengig, men i mindre grad enn konvensjonell ultralydundersøkelse. Det kan være varierende grad av innsyn, særlig gjelder det adipøse pasienter. Kontrastmidlet er kontraindisert for pasienter med nylig akutt koronarsykdom eller ustabil iskemisk hjertesykdom.

\section{Kjell Morten Rokseth}

kjell.morten.rokseth@stolav.no

Erik Magnus Berntsen

Klinikk for bildediagnostikk

St. Olavs hospital

Kjell Morten Rokseth (f. 1978) er lege i spesialisering i radiologi og konstituert overlege ved gastroradiologisk seksjon ved.

Forfatter har fylt ut ICMJE-skjemaet og oppgir

ingen interessekonflikter.
Erik Magnus Berntsen (f. 1982) er ph.d. og lege i spesialisering i radiologi.

Forfatter har fylt ut ICMJE-skjemaet og oppgir ingen interessekonflikter.

\section{Litteratur}

1. Nasjonalt handlingsprogram med retningslinjer for diagnostikk, behandling og oppfølging av tykkog endetarmskreft. IS-1594. Oslo: Helsedirektoratet, 2012

2. Danila M, Popescu A, Sirli R et al. Contrast enhanced ultrasound (CEUS) in the evaluation of liver metastases. Med Ultrason 2010; 12: 233-7.

Mottatt 18.5. 2012, første revisjon innsendt 29.7. 2012, godkjent 9.8. 2012. Medisinsk redaktør Merete Kile Holtermann. 